\title{
PENINGKATAN MUTU PHYSICAL EVIDENCE DI SEKOLAH DASAR MELALUI GERAKAN TOILET RAMAH ANAK
}

\author{
Indah Purnama Sari, Septiana Ikaningtyas, Laila Desnaranti \\ Dosen Program Studi Pendidikan Ekonomi \\ Fakultas Ilmu Pendidikan dan Pengetahuan Sosial \\ Universitas Indraprasta PGRI \\ indah.mabesnet@gmail.com,tyasseo709@gmail.com,lailaranti@g,mail.com
}

\begin{abstract}
Abstrak
Quality of an education institution can be observe from physical evidence like the look and smells in the school toilet. School toilet that smell and dirty like happen in most school also happen in partners school, SDN Tengah 09 Pagi Kramat Jati Jakarta Timur. Because of that our society servant team (ABDIMAS) made a proggrame named Kids Friendly Toilet Campaign with the purpose to enhance the quality of physical evidence state school through socialization of an ideal concept students toilet. This proggrame done through three steps; first socialization to the teacher and the school guard, second cleaning and toilet rehabilitation and third socialization to the students. Students socialization step is done by presentation about the important of keeping the toilet clean, watched video, coloring competition and demonstrate how to clean the toilet with the students. This activity goes well doesn't have any problem an able to give positive change for the school, like increasing the quality of student toilet facility that more friendly (beside clean, educative, green environment and also included with CCTV), so the students will have more positive attitude in keeping the cleaness of toilet, increasing the students caring character, discipline and train student patient. therefore this proggrame help students in developing the values, making a strong character to a healthy life and also helps school internalitation positive values as a provition for the students to face steps of next growth and development. Beside that the more of the quality of the physical evidence hoping will to push the total quality from school management.
\end{abstract}

Keywords : psychical evidence, keep friendly toilet

\section{PENDAHULUAN}

Setiap lembaga baik yang berorientasi pada profit maupun non provit memerlukan manajemen untuk bisa bertahan dan unggul. Sekolah negeri merupakan salah satu contoh lembaga non profit yang dibiayai oleh pemerintah. Sekolah negeri harus dikelola dengan baik sebagai bentuk profesionalisme lembaga serta tanggung jawab kepada Negara. Oleh karena itu pengelola sekolah negeri perlu mengenali faktor-faktor yang dikuasainya dan dapat digunakan untuk mem- pengaruhi keputusan orang tua siswa atau siswa dalam memilih sekolah. Harapannya, sekolah negeri tersebut dapat menjadi tujuan utama (sekolah favorit) para calon siswa yang berkualitas baik. Dalam bidang pemasaran, faktor-faktor tersebut dikenal dengan istilah bauran pemasaran atau marketing mix, yang meliputi $7 \mathrm{P}$ (product, price, place, promotion, people, process dan physical evidence).

Physical evidence (fasilitas pendukung) merupakan bagian dari pemasaran jasa yang memiliki peranan cukup penting. Kondisi physical evidence di sekolah perlu dikaji karena 
sekolah merupakan rumah kedua bagi anak. Dalam sehari, seorang anak menghabiskan waktu lebih kurang 6 jam di sekolah, bahkan bisa lebih. Masih banyak kondisi toilet di sekolah-sekolah, baik Sekolah Dasar, Sekolah Menengah Pertama maupun Sekolah Menengah Atas yang memprihatinkan, menunjukkan penggunanya belum mengerti pentingnya menjaga kebersihan toilet.

Kondisi tersebut tentu sangat ironis. Sekolah sebagai tempat mengajarkan kebersihan dan kesehatan kepada anak didik, justru tidak sanggup mengurus sarana sanitasi serta tidak sanggup menyediakan-nya dalam jumlah yang ideal, padahal kebutuhan hajat manusia terhadap fasilitas sanitasi tidak dapat ditunda. Di sisi lain, masih minimnya jumlah toilet serta kurang terjaganya kebersihan toilet yang ada di sekolah-sekolah di Indonesia, akan menjadi sarang penyakit dan berdampak buruk bagi proses pendidikan di sekolah.

Walaupun jarang diangkat ke permukaan, masalah toilet telah menjadi masalah dunia. Tanggal 19 November ditetapkan oleh PBB menjadi Hari Toilet Sedunia. Jadi, sebagai sarana sanitasi yang mempengaruhi kesehatan, keberadaan toilet bukan hal yang sepele atau perlu disepelekan. Kualitas sebuah lembaga pendidikan salah satunya bisa dinilai dari physical evidence seperti tampak dan aroma yang terdapat di toilet sekolah.

Toilet sekolah kotor dan berbau tak sedap seperti terjadi di kebanyakan sekolah juga terjadi di sekolah mitra, yaitu SD Negeri Tengah 09 Pagi Kramat Jati Jakarta Timur. Berdasarkan hasil pengamatan kondisi toilet siswa masih belum ideal.
Menurut Kepala Sekolah, sekolah sudah memiliki seorang petugas kebersihan (merangkap sebagai penjaga sekolah) yang salah satu tugasnya adalah membersihkan toilet siswa. Namun pada kenyataannya toilet masih terlihat kotor dan berbau tak sedap.

Adapun tujuan dari program Gerakan Toilet Ramah Anak ini adalah untuk membantu sekolah mengatasi masalah toilet yang senantiasa kotor, berbau tak sedap, membudayakan program Toilet Ramah Anak di lingkungan sekolah khususnya Sekolah Dasar, membantu menguatkan sikap positif siswa terhadap kegiatan menjaga kesehatan dan kebersihan lingkungan termasuk toilet sekolah, serta mengingatkan masyarakat bahwa tanggal 19 November telah ditetapkan PBB sebagai Hari Toilet Sedunia.

\section{Target dan Luaran}

Peserta aktif dalam kegiatan pengabdian masyarakat ini adalah siswa kelas 3 sampai dengan kelas 5 SD Negeri Tengah 09 Pagi Jakarta Timur semester genap Tahun Pelajaran 2015/2016. Pemilihan siswa tersebut berdasarkan pendapat ahli bahwa masa usia sekolah (6-12 tahun) adalah masa yang tepat untuk memenuhi tugas perkembangan mencapai kemandirian pribadi di antaranya adalah kemampuan membina hidup sehat (Desminta, 2011: 35). Selain itu, jika dilihat dari frekuensi kebutuhan terhadap toilet, siswa SD memiliki kebutuhan yang lebih sering dibandingkan akan usia SMP maupun SMA. Semakin besar usia seorang anak, kebutuhan menggunakan toilet akan semakin sebentar.

Luaran dalam kegiatan ini diuraikan dalam tabel 1 berikut ini:

Tabel 1. Luaran Kegiatan Pengabdian kepada Masyarakat

\begin{tabular}{lll}
\hline No & Luaran & \multicolumn{1}{c}{ Spesifikasi } \\
\hline 1. & Jasa & $\begin{array}{l}\text { Pendampingan Program Toilet Ramah Anak di sekolah serta sosialisasi } \\
\text { untuk lebih memperhatikan kondisi sanitasi, utamanya toilet }\end{array}$ \\
\cline { 3 - 3 } & $\begin{array}{l}\text { Memberi referensi tentang kriteria toilet sekolah yang ideal serta jenis-jenis } \\
\text { tanaman antipolutan yang dapat digunakan di dalam toilet }\end{array}$ \\
\hline
\end{tabular}




\begin{tabular}{lll}
\hline & $\begin{array}{l}\text { Memperkuat pemahaman siswa tentang budaya hidup sehat, salah satunya } \\
\text { dengan menjaga kebersihan toilet }\end{array}$ \\
\cline { 3 - 3 } & $\begin{array}{l}\text { Membangun sikap positif siswa terhadap fasilitas sekolah, bahwa toilet } \\
\text { siswa bersih, aman, nyaman, hijau }\end{array}$ \\
\cline { 3 - 3 } & Memperkuat karakter siswa dalam menjaga kebersihan lingkungan sekolah \\
\hline 2. & Metode & $\begin{array}{l}\text { Metode pengadaan ruang toilet sekolah yang ideal, dalam konsep "Toilet } \\
\text { Ramah Anak" }\end{array}$ \\
\cline { 3 - 3 } & $\begin{array}{l}\text { Metode manajemen toilet yang melibatkan siswa kelas 4, } 5 \text { dan 6 dengan } \\
\text { cara membentuk jadwal piket toilet siswa }\end{array}$ \\
\cline { 3 - 3 } & & $\begin{array}{l}\text { Metode edukasi pentingnya menjaga kebersihan siswa melalui media } \\
\text { audiovisual dan gambar poster }\end{array}$ \\
\hline 3 & Model & Sekolah model penerapan toilet ramah anak \\
\hline 4 & Publikasi & Jurnal ilmiah \\
\hline
\end{tabular}

\section{METODE PELAKSANAAN}

Dalam upaya mencapai target maka tim merancang kegiatan pengabdian kepada masyarakat ini dengan topik yang lebih praktis, yaitu Gerakan Toilet Ramah Anak. Kegiatan ini merupakan kampanye edukatif yang dilakukan kepada lingkungan Sekolah Dasar Negeri di wilayah DKI Jakarta. Sebagai sekolah model untuk Wilayah Administratif Jakarta Timur adalah SDN Tengah 09 PagiKramat Jati.

Praksis pelaksanaan program efektif dilakukan pada 3 (tiga) sesi, yaitu sesi pertama pada hari Kamis, tanggal 28 April 2016 sosialisasi program kepada pihak sekolah mitra, yang dihadiri oleh Dewan Guru, Tata Usaha serta Petugas Kebersihan (Penjaga Sekolah). Sosialisasi ini berjalan lancar dimulai dari Pk. 08,00 s.d 10.00. Acara sosialisasi ini merupakan agenda lanjutan dari hasil diskusi Tim dengan Kepala Sekolah, sehingga yang dipaparkan adalah kesepakatan program antara pihak Tim Abdimas dengan Kepala Sekolah. Tatap muka antara Tim dengan Kepala Sekolah sebelum tanggal 28 April 2016 telah dilakukan sebanyak 2 (dua) kali, yaitu pada tanggal 9 April 2016 untuk melakukan tanda-tangan kontrak MOU Abdimas, dan tanggal 13 April 2016 untuk diskusi program.
Dalam acara sosialisasi ini Tim memaparkan konsep kegiatan, rundown acara, serta Sepuluh Konsep Toilet Ramah Anak yang menjadi isu utama. Jumlah peserta yang hadir dalam kegiatan sosialisasi ini 15 orang, terdiri dari 3 orang Tim Abdimas, 1 orang TU, 1 orang Penjaga sekolah, dan 10 orang Dewan Guru. Pada sesi Tanya jawab (diskusi), dewan guru cukup antusias memberikan pertanyaan serta saran usul kepada Tim terkait program yang telah direncanakan. Peserta menyambut positif program ini dan mendukung secara penuh, walau pada sesi inti tidak semua kelas (wali kelas) terlibat. Dewan guru juga memberikan berbagai usul terkait pengadaan barang perlengkapan toilet dan rehabilitasi toilet. Tentu saja tim menyikapi usul ini dengan bijak karena keterbatasan dana. Mengenai hal ini forum dapat memaklumi.

Sesi kedua, yaitu hari Minggu, tanggal 1 Mei 2016 dengan agenda Kerja Bakti Rehabilitasi Toilet Siswa. Pada sesi kedua ini, jumlah peserta sebanyak 12 orang, terdiri dari 3 orang Tim Abdimas, 5 orang mahasiswa sebagai tim pendukung, 2 orang sukarelawan (teknisi), 1 orang guru, dan 1 orang penjaga sekolah. Kegiatan berlangsung mulai pagi, Pk. 08.00 hingga sore Pk. 16.30 WIB. Kegiatan yang dilakukan berupa kerja bakti, pengecatan, rehabilitasi pintu, penyiapan taman mini 
toilet, pemasangan CCTV dan persiapan agenda sesi 3 (keesokan harinya, yaitu Senin, 2 Mei 2016).

Sesi ketiga, Senin, 2 Mei 2016 adalah hari yang ditunggu-tunggu baik oleh pihak Tim Abdimas maupun siswa. Bertepatan dengan memperingati Hari Pendidikan Nasional, Tim Abdimas menyuguhkan sebuah acara di sekolah, yaitu edukasi toilet ramah anak kepada siswa dalam kemasan acara menonton video edukasi, pemaparan materi, kerja bakti membersihkan toilet oleh siswa serta lomba mewarnai poster edukasi. Sebanyak 5 kelas dilibatkan dalam acara ini namun melalui perwakilan siswa, tiap kelas mengirimkan 5 orang wakil. Kelas yang dipilih untuk mengikuti kegiatan ini adalah kelas $3 a$ dan $3 b$, kelas $4 a$ dan $4 \mathrm{~b}$, serta kelas 5, sehingga total peserta yang berasal dari siswa adalah 25 orang.

Acara ini dipandu olwh Tim Abdimas dibantu oleh 5 orang mahasiswa. Mahasiswa membantu proses registrasi peserta, pendampingan kegiatan, penjurian lomba, serta konsumsi. Pada proses registrasi, siswa yang menjadi peserta mendapat nametag khusus. Acara ini dibuka oleh Tim dengan menonton video, dilanjutkan dengan memberikan arahan pada siswa terkait pentingnya menjaga kebersihan toilet. Acara yang ditutup dengan sesi doorprize. ini berdurasi 30 menit. Kemudian mahasiswa membagi peserta kedalam 2 kegiatan, yaitu kerja bakti yang dilakukan oleh siswa kelas 5 dan lomba mewarnai oleh siswa kelas 3 dan kelas 4. Durasi yang direncanakan selama 1 jam ini kemudian ditambah 30 menit karena mayoritas peserta belum menyelesaikan posternya. Ada 4 jenis poster yang diberikan secara acak. Poster ini berukuran kertas A3, dan siswa mewarnai menggunakan alat pewarna crayon dan pensil warna. Setelah waktu mewarnai berakhir, dilakukan penilaian oleh dewan juri. Juri yang terlibat adalah
3 orang, terdiri dari unsur guru, dosen, dan mahasiswa. Pada saat proses penilaian berlangsung, siswa kelas 3, 4 dan kelas 5 dikumpulkan lagi untuk diberi konsumsi. Sesi ini dikelola sepenuhnya oleh mahasiswa. Dalam hal ini mahasiswa mendapat pembelajaran berharga, yaitu keberanian berbicara di depan umum, dan berinteraksi langsung dengan siswa. Adapun dewan guru tidak semuanya terlibat, karena proses belajar mengajar tetap terlaksana dengan normal dan tidak terganggu dengan kegiatan ini. Dewan guru yang terlibat, pada hari tersebut mendapat pengarahan dari teknisi cara mengaktifkan dan memantau aktifitas di toilet siswa melalui rekaman CCTV yang dapat diakses melalui monitor computer PC, laptop, notebook, maupun layar HP android. Acara kemudian dilanjutkan dengan pengumuman pemenang dan penyerahan piala. Hasil poster juara 1, 2 dan 3 kemudian dipajang di ruangan toilet siswa sebagai media edukasi sekaligus motivasi bagi siswa. Tim abdimas juga memberikan beberapa perkakas toilet untuk sekolah yang didanai oleh Universitas Indraprasta PGRI melalui program hibah pengabdian kepada masyarakat.

Setelah acara penutupan, Tim mendapat kehormatan dari pihak Lembaga (Universitas Indraprasta PGRI) karena Ketua Program Studi bersedia untuk meninjau lokasi. Bapak H. Sefudin, S.E., MM dan rombongan tiba di sekolah pada Pk. 12.30. Pada kesempatan ini Tim monitoring dari Program Studi meninjau langsung lokasi (toilet siswa), ruangan aula tempat berlangsungnya kegiatan, ruangan guru untuk mengkonfirmasi langsung kepada guru terkait kegiatan yang telah dilakukan Tim Abdimas prodi Pendidikan Ekonomi, menyaksikan proses pengawasan toilet melalui rekaman CCTV yang didemokan oleh 
guru, serta bersilaturahmi dengan Kepala Sekolah. Hasil yang diperoleh dari pertemuan ini adalah sekolah sangat berterima kasih dan mengapresiasi program yang telah dilaksanakan oleh Universitas Indraprasta PGRI. Sekolah juga menyampaikan beberapa tema permasalahan lainnya yang dapat angkat menjadi tema penelitian dan pengabdian masyarakat pada periode-periode selanjutnya. Sekolah berharap kerjasama ini bersifat kontinyu, dan dapat menyentuh aspek yang lain. Ketua Program Studi Pendidikan Ekonomi menanggapi dengan baik saran-saran dari sekolah, dan berkomitmen untuk meneruskan program yang telah dimulai oleh Tim Abdimas ini sehingga dapat menyentuh permasalahan-permasalahan lain yang dialami oleh sekolah. Acara di hari terakhir ditutup dengan foto bersama dan Tim Abdimas serta rombongan kemudian meninggalkan sekolah pada Pk. 14.00 WIB.

Pada tahap berikutnya, Tim Abdimas tetap memantau pelaksanaan program Toilet Ramah Anak ini melalui konfirmasi kepada siswa mengenai kondisi toilet saat ini. Pada umumnya siswa menyatakan senang dan bangga karena toiletnya kini bersih, dan dilengkapi CCTV. Siswa juga mentaati salah peraturan baru di toilet sekolah, misalnya melepas sepatu ketika masuk toilet, menggunakan alas kaki khusus toilet (telah disediakan), masuk ke kamar toilet sesuai jenis kelaminnya. SDN Tengah 09 Pagi dengan kapasitas siswa 300 orang hanya memiliki toilet siswa sebanyak 2 pintu. Sebelum dilakukan program toilet siswa ini kondisinya sangat memprihatinkan, dan bercampur antara toilet laki-laki dan perempuan. Saat ini telah dibagi kamar khusus untuk putra dan putri. Dewan guru juga merasa sangat terbantu dengan adanya kamera CCTV sehingga hal-hal yang tidak diinginkan yang dapat terjadi di toilet lebih bisa diantisipasi. Prinsip mencegah lebih baik daripada mengobati. Pengawasan toilet juga lebih leluasa, guru tidak perlu meninjau langsung, selama berada di lingkungan sekolah yang mendapat akses WIFI maka guru bisa langsung memantau aktifitas siswa di toilet. Hasil nyata yang didapat oleh sekolah adalah kondisi physical efidence yang terkait dengan fasilitas sanitasi menjadi lebih baik. Spanduk bertuliskan "Sekolah Model Penerapan Toilet Ramah Anak" yang terpajang indoor dan outdoor dapat menjadi media promosi dan citra baik dari wali murid, kolega sekolah lain, maupun dari Dinas PEMDA terkait yang terkadang melakukan pemantauan, seperti Dinas Pendidikan, dan Dinas Kesehatan. Semua siswa dipastikan telah mengetahui bahwa ruangan toilet kini telah dilengkapi dengan CCTV dan berlaku beberapa peraturan baru. Hal ini karena semua wali kelas telah diinstruksikan untuk memberikan sosialisasi terkait kondisi dan peraturan toilet yang baru. Peraturan toilet yang baru juga ditempel di setiap pintu masuk kelas sehingga dapat terbaca dengan jelas oleh siswa. Bahkan ada beberapa kelas yang berinisiatif untuk memiliki alas kaki toilet khusus kelas. Beberapa orang tua murid yang berhasil ditemui oleh Tim juga telah mengetahui kondisi toilet siswa siswa berdasarkan penuturan putra putrinya.

Tim Abdimas melakukan kunjungan (monitoring) ke sekolah untuk pertama kali pada tanggal 18 Juli 2016 bertepatan dengan hari pertama masuk sekolah setelah libur panjang kenaikan kelas dan Idul Fitri. Yang dilakukan dalam monitoring selama 2 jam ini (Pk. 08.00 sampai dengan Pk.10.00) adalah mengobservasi jalannya program, mengidentifikasi kendala yang dialami sekolah, membantu pihak sekolah mengatasi kendala tersebut serta 
melakukan konfirmasi (wwancara) untuk mengetahui tanggapan guru maupun siswa terkait program yang telah dijalankan. Adapun hasilnya dirangkum sebagai berikut:

1. Hasil wawancara dengan Guru

a. Bapak "A"

Menurut Bapak "A", dengan adanya toilet ramah anak, siswa menjadi lebih tertib apabila ingin ke toilet dan mereka juga tidak lupa untuk menyiram toilet setelah digunakan karena terdapat tulisan yang mengingatkan. Para guru juga tidak lupa mengingatkan para siswa agar melepaskan sepatu dam menggantinya dengan sandal apabila masuk ke dalam toilet.

b. Bapak "B"

Pendapat Bapak."B" terhadap toilet ramah anak adalah adanya perubahan yang positif secara signifikan, seperti: sudah berkurangnya bau yang tidak sedap dari dalam toilet siswa dan lebih teraturnya siswa jika ingin ke toilet karena setiap kelas hanya tersedia 2 pasang sandal jepit maka siswa yang ke toilet tidak lagi berkelompok. Respon dari siswa juga positif menurut Bapak "B", sebab tidak terdapatnya keluhan dari siswa yang harus melepas sepatu sebelum masuk ke dalam toilet. Kebersihan toilet juga meningkat karena siswa harus melepaskan sepatu sebelum masuk toilet. Peranan guru juga sangat baik dengan selalu mengingatkan siswa harus melepaskan sepatu. Siswa juga merasa lebih aman dengan adanya CCTV di dalam toilet. Menurut Bapak "B" terdapat penurunan dalam hal pengaduan siswa mengenai gangguan dari siswa lain yang mereka alami di dalam toilet berkat adanya CCTV.

c. Ibu "C"

Adanya perubahan dalam hal displin karena terdapat tata tertib yang jelas yang ditempel di dinding sekitar toilet. Tidak terdapatnya keluhan dari guru yang mengajar di kelas 1 dan 2 mengenai keharusan siswanya melepaskan sepatu setiap ingin ke toilet. Semoga dengan adanya piket kebersihan toilet, kebersihan dan kenyamanan toilet dapat terjaga.

d. Bapak "D"

Terdapat perubahan yang positif dengan terdapatnya kesadaran yang tinggi dalam menjaga kebersihan toilet. Siswa menggunakan toilet tidak berkelompok karena maksimal siswa yang menggunakan toilet hanya 2 orang sesuai dengan jumlah sandal di tiap kelas. Siswa merespon positif atas adanya CCTV karena siswa merasa terpantau sehingga tingkat kedisplinan menjadi lebih meningkat. Siswa juga mejadi lebih peduli terhadap kebersihan toilet dengan melepakan alas kaki sebelum masuk serta menyiram kembali toilet setelah digunakan. Seluruh siswa juga turut menjaga kebersihan bahkan siswa kelas 1 dan 2, meskipun untuk kelas 1 dan 2 perlu pengawasan dari wali kelasnya tetapi para siswa antusias dalam menjaga kebersihan.

2. Hasil wawancara dengan siswa

a. Ananda "E" (5A)

"E" merasa toilet yang baru ini berbeda dengan yang lama. Toilet lebih nyaman, aman, dan tidak bau. Naufal tidak merasa 
repot untuk melepaskan sepatunya sebelum masuk ke dalam toilet.

b. Ananda "F"(5A)

Menurut "F" toilet yang sekarang lebih bersih. Sudah tidak ada lagi yang mencorat-coret dinding toilet. Indah juga merasa tidak sulit untuk melepaskan sepatunya sebelum masuk ke dalam toilet.

c. Ananda " $G$ " (5A)

"G" merasakan adanya perbedaan dengan toilet yang lama. Toilet yang sekarang lebih bersih, tidak bau, dan aman.

d. Ananda " $\mathrm{H}$ " (5A)

"H" merasakan toilet yang baru ini lebih nyaman dan bersih. Maulia juga tidak merasa kerepotan harus melepaskan sepatu sebelum masuk ke dalam toilet.

e. Ananda "I" (5A)

"I" berpendapat bahwa toilet yang sekarang lebih nyaman, aman, dan Rosa tidak merasa repot harus melepaskan sepatu sebelum masuk toilet.

f. Ananda "J" (5B)

"J" berpendapat toilet yang sekarang lebih bersih dan lebih baik dari toilet yang sebelumnya.

g. Ananda "K" (5B)

"K" merasakan toilet lebih bersih, lebih wangi, dan lebih aman dibandingkan dengan toilet yang sebelumnya.

h. Ananda "L" (5B)

Menurut "L" toilet sudah lebih baik karena sudah berkurangnya bau yang tidak sedap serta lebih aman dengan adanya CCTV.

i. Ananda "M" (5B)

"M berpendapat bahwa toilet yang sekarang sudah lebih bersih, tidak adanya coretan di dinding dan Adika merasa lebih aman karena terpantau oleh guru melalui CCTV yang terdapat di dalam toilet.

j. "M" (5B)

Menurut " $M$ " toilet yang sekarang lebih bersih karena para siswa menyiram toilet sesudah menggunakan dan melepaskan sepatu sebelum masuk ke dalam toilet.

Secara keseluruhan program ini berhasil dilaksanakan dengan baik, sesuai dengan yang telah direncanakan sebelumnya dan tidak mengalami kendala apapun. Dukungan penuh dari pihak sekolah baik dari Kepala Sekolah maupun dewan guru mengambil peran penting dalam kesuksesan program abdimas ini. Sekolah juga tidak mengalami kendala dalam penerapan toilet ramah anak, kecuali kuantitas toilet yang sangat tidak sebanding dengan jumlah siswa menyebabkan antrian utamanya setelah setelah pelajaran olah raga karena siswa 1 kelas (lebih kurang 30 orang) harus berganti seragam di 2 toilet. Kendati demikian, siswa masuk toilet dengan tertib dengan antrian 2 orang masuk, diganti dengan 2 orang berikutnya.

Program lanjutan untuk kegiatan Pengabdian Kepada ,Masyarakat dengan tema Gerakan Toilet Ramah Anak ini akan dilaksanakan pada semester Ganjil 2016/2017. Untuk menstimulasi SD-SD lainnya turut mengupayakan Gerakan Toilet Ramah Anak di sekolah masingmasing, Tim berencana untuk bermitra dengan Dinas Pendidikan khususnya wilayah Jakarta Timur menyelenggarakan sosialisasi penerapan toilet ramah anak di sekolah. Kegiatan sosialisasi ini akan dilanjutkan dengan pendampingan dari Tim Abdimas. Kegiatan ini akan bertempat di SDN Tengah 09 Pagi Kramat Jati sebagai Sekolah Model. Adapun pembicara diupayakan dari pihak Tim Abdimas, Kepala Sekolah 
SDN Tengah 09, Dinas Pendidikan dan Dinas Kesehatan, serta KPAI.

\section{SIMPULAN}

1. Pengabdian kepada Masyarakat dengan judul "Peningkatan Mutu Physical Evidence di Sekolah Dasar Melalui Program Toilet Ramah Anak" berhasil terselenggara dengan baik, saat ini berada pada tahap monitoring program oleh Tim Abdimas Unindra.

2. Selama program berlangsung tidak mengalami kendala yang berarti karena mendapat dukungan penuh dari sekolah mitra serta dalam pelaksanaan secara teknis didukung pula oleh mahasiswa Unindra sebanyak 5 orang mahasiswa.

3. Hasil yang dicapai dalam pelaksanaan program adalah adanya peningkatan mutu physical evidence terkait fasilitas kesehatan (sanitasi) di sekolah, yaitu toilet siswa. Peningkatan mutu ini dapat dilihat dari tanggapan positif yang diberikan baik dari Guru maupun dari siswa sebagai pengguna toilet siswa.

4. Upaya peningkatan mutu physical evidence toilet siswa dengan slogan "Toilet Ramah Anak" mampu memberikan perubahan-perubahan positif terhadap perilaku siswa dalam menggunakan fasilitas toilet sekolah. Perilaku terpuji yang ditunjukkan siswa adalah lebih disiplin dalam mentaati peraturan toilet yang baru seperti melepas sepatu, menggunakan sandal khusus toilet, mengantri, menyiram toilet sampai bersih, tidak menyoret tembok, dan sebagainya. Siswa juga belajar sabar menunggu antrian karena setiap kelas hanya menyediakan 2 pasang sandal khusus toilet, sehingga siswa tidak masuk toilet secara bergerombol. Hal penting lainnya berdasarkan laporan guru, adanya CCTV menekan jumlah pengaduan dari siswa tentang kenakalan teman yang terjadi di toilet. Siswa juga merasa lebih aman berada di toilet karena adanya CCTV, dalam hal ini siswa merasa selalu terpantau aktivitasnya. Berkat program Gerakan Toilet Ramah Anak, siswa SDN Tengah 09 Pagi kini memiliki toilet yang bersih, aman, nyaman, dan hijau.

5. Dana hibah pengabdian kepada masyarakat telah disalurkan dengan amanah sesuai kehendak Perjanjian Pelaksanaan Tugas Pengabdian Kepada Masyarakat dengan Lembaga Penelitian dan Pengabdian Kepada Masyarakat Universitas Indraprasta PGRI.

\section{DAFTAR PUSTAKA}

Nirwana. (2004). Prinsip-prinsip Pemasaran Jasa. Dioma, Malang

Nugroho, R. dan Japarianto, E. (2013) Pengaruh People, Physical Evidence, Product, Promotion, Price dan Place terhadap Tingkat Kunjungan di Kafe Coffee Cozies Surabaya. Jurnal Manajemen Pemasaran Petra Vol. 1, No. 2, hal 1-9

news.okezone.com/read/2015/.../aksisaling-contek-warnai-ujiannasional, diakses 22 Februari 2016.

http://health.detik.com/read/2015/11/17/ $\underline{113241 / 3072984 / 763 / \text { hari-toilet- }}$ sedunia, diakses 22 februari 2016. 